\title{
CHANGE IN THE TERPENOID PROFILE AND SECONDARY GROWTH IN DECLINING STANDS OF PINUS SYLVESTRIS L. UNDER MEDITERRANEAN INFLUENCE AS A RESPONSE TO LOCAL FACTORS
}

\section{Cambios en el perfil terpénico y en el crecimiento secundario en poblaciones en decaimiento de Pinus sylvestris L. bajo influencia mediterránea en respuesta a factores locales}

\author{
M.A. Sanz ${ }^{1}$ J. Sánchez², J.J. Camarero ${ }^{3}$, J.J. Peguero-Pina ${ }^{1,4}$, D. Sancho-Knapik ${ }^{1}$ \& E. Gil-Pelegrín ${ }^{1, *}$ \\ ${ }^{1}$ Centro de Investigación y Tecnología Agroalimentaria, Gobierno de Aragón, 50059, Zaragoza, Spain \\ 2 Instituto Nacional de Toxicología y Ciencias Forenses. C/ La Merce 1, 08002, Barcelona, Spain \\ ${ }^{3}$ ARAID, Instituto Pirenaico de Ecología (CSIC). Apdo. 13034, 50080 Zaragoza, Spain \\ ${ }^{4}$ Grup de Recerca en Biologia de les Plantes en Condicions Mediterrànies, Departament de Biologia, Universitat de les Illes Balears, Carretera \\ de Valldemossa, km 7.5, 07071, Palma de Mallorca, Balears, Spain \\ *Author for correspondence. E-mail: egilp@aragon.es
}

\begin{abstract}
Recibido: 13-01-2014. Aceptado: 20-02-2014. Fecha de publicación on-line: 08/09/2014
Citation / Cómo citar este artículo: Sanz, M. A., Sánchez, J., Camarero, J. J., Peguero-Pina, J. J., Sancho-Knapik, D. \& Gil-Pelegrín, E. (2014). Change in the terpenoid profile and secondary growth in declining stands of Pinus sylvestris L. under Mediterranean influence as a response to local factors. Pirineos, 169, e003. doi: http://dx.doi.org/10.3989/Pirineos.2014.169003

ABSTRACT: The terpenoid profile could give information about the water status in Scots pine, especially for trees growing in the same geographical area but under contrasting local environmental conditions. Terpenes were analyzed by gas chromatography-mass spectrometry in needles, twigs and wood of ten affected and ten unaffected Scots pines in the southern "Sistema Ibérico" range (Teruel, Spain), where forest decline has been recently reported. Soil depth and secondary growth was also studied in both types of trees. Needles and twigs total resin acids were significantly higher in affected trees. The pimarane type resin acids were also higher in the twigs of affected trees. Secondary growth was lower in affected trees and it showed higher climate sensitivity. The use of the terpenoid profile may be used as an additional tool for the estimation of the water status, especially for situations inducing moderate but relatively prolonged stress conditions.
\end{abstract}

KEYWORDS: Monoterpenes; soil; resin acids; Scots pine; stress

RESUMEN: El perfil terpénico podría dar información sobre el estado hídrico en el pino albar, especialmente cuando se comparen especímenes de una zona geográfica concreta afectados por factores ambientales locales. Los terpenos de acículas, brotes del año y madera fueron analizados en diez ejemplares afectados y otros tantos no afectados por el decaimiento mediante cromatografía de masas acoplada a espectrometría de masas. La serie de crecimiento secundario en ambos tipos de ejemplares fue también estudiada. La concentración total de ácidos resínicos aumentó de modo 
significativo en los árboles afectados tanto en brotes del año como en acículas. La cantidad de ácidos de tipo pimarano también aumentó en los brotes de los árboles afectados. La profundidad del suelo y el crecimiento secundario era menor en este tipo de ejemplares, que muestran una mayor sensibilidad en términos dendrocronológicos. El perfíl terpénico podría utilizarse como una herramienta adicional a la estimación del estado hídrico, especialmente cuando el árbol está afectado por condiciones de estrés moderadas pero prolongadas en el tiempo.

PALABRAS CLAVE: Monoterpenos; suelo; ácidos resínicos; pino albar; estrés

\section{Introduction}

Pinus sylvestris L. reaches some of its southern distribution limits in different mountain ranges of the Iberian Peninsula (Matías \& Jump, 2012). In these southern populations, Scots pine is restricted to specific altitudinal ranges (Alía et al., 2001), most of them in a scattered distribution pattern (Galiano et al., 2010) and under climatic conditions far from those existing in the rest of the palearctic distribution area (Andersson \& Fedorkov, 2004). In these habitats, the Mediterranean influence in the climate induces the existence of a summer drought period, which might be locally amplified in some specific locations with very shallow soils (Poyatos et al., 2008).

Recently, several authors have reported drought-related decline episodes in populations of $P$. sylvestris located near its southern distribution limit, which seem to be very sensitive to an increase in the aridity (Martínez-Vilalta \& Piñol, 2002; Galiano et al., 2010; Peguero-Pina et al., 2011; Candel-Pérez et al., 2012). Peguero-Pina et al. (2011) described a massive episode of Scots pine decline in the populations included in the "Sierra de Gúdar" (Sistema Ibérico, Teruel, Spain) provenance region (Catalán et al., 1991). The process was characterized by a general needle yellowing followed by severe defoliation and whole branch death in a great percentage of trees. Furthermore, trees living in areas with deeper soils were not affected by this process. These two kind of trees showed marked differences in the minimum xylem water potential through the year and, more specially, in the driest period of the summer of 2005 and 2006 (Peguero-Pina et al., 2011).

The influence of summer drought in these extreme populations may be monitored through the direct measurements of water status related variables, such as water potential or water content. On the other hand, the use of long-term plant responses to water stress could provide an additional and more integrated overview about tree water status. The evaluation of water stress based on the accumulation of some metabolic compounds, such as proline (Xiaou et al., 2008) or abscisic acid (ABA) (Corcuera et al., 2012) have been proposed as a possible tool for these integrative approaches. In this sense, it has also been suggested that the composition of the oleoresin in P. sylvestris can be modulated by different environmental factors (Kainulainen et al., 1996), including drought (Turtola et al., 2003). A similar effect has been described in other conifer species, such as Picea abies (Kainulainen et al., 1992), Pinus resinosa
(Blodgett \& Stanosz, 1996) or P. halepensis (Llusia \& Peñuelas, 1998). Drought can also influence the constitutive oleoresin flow produced by pine species and not only the composition or terpenoid profile. Thus, while a moderate water stress can induce a higher production of oleoresin (Lombardero et al., 2000), a more severe water deficit can severely reduce its constitutive flow (Croisé \& Lieutier, 1993).

From this perspective, the aim of this work is the study of the possible differences in the composition of the oleoresins in the two sets of Scots pine specimens above mentioned, affected and unaffected by crown defoliation and branch death. This study is complemented with a soil study and a dendrochronological analysis of trees from these two sets in order to evaluate the influence of the environmental conditions on tree growth.

\section{Materials and Methods}

\subsection{Study site}

The study was performed in a natural population of Scots pine located in the southern "Sistema Ibérico" range ( $40^{\circ} 30^{\prime} \mathrm{N}, 0^{\circ} 36^{\prime} \mathrm{E}, 1650 \mathrm{~m}$ a.s.l., Teruel, Spain). Mean annual precipitation recorded in the nearby meteorological station during the period 1997-2003 was $510 \pm 21 \mathrm{~mm}$. This population is over degraded soils characterized by the presence of superficial calcareous substrates that are very scarce and highly variable in depth. In this study we distinguished two kinds of trees: i) trees without any symptom of defoliation (thereafter unaffected trees) and ii) trees with evident symptoms of defoliation in the $S$ face of the crown (thereafter affected trees), according to Peguero-Pina et al., (2011). Measurements were carried out in ten affected and ten unaffected trees, randomly selected. The distance between the two sampling areas (unaffected and affected trees) was ca. $500 \mathrm{~m}$ in a flat area implying that both areas was equivalent in terms of exposition and slope. In case of affected trees, we selected branches with a high degree of defoliation, but still maintaining living needles evenly distributed along the branch.

\subsection{Dendroecology}

Two cores per tree obtained from each one of the studied trees (ten affected and ten unaffected) were air dried and sanded with papers of progressively finer 
grain until tree rings were clearly visible. Two opposite radii were selected in each section and they were visually cross-dated for the period 1980-2005. Then, tree-ring widths were measured to a resolution of 0.01 mm using a semiautomatic device (LINTAB, Frank Rinn, Heidelberg, Germany). The visual cross-dating was checked with the software COFECHA (Holmes, 1983). Individual tree chronologies were built from cross-dated ring-width series using the ARSTAN program by using a two-step detrending procedure (Cook, 1985). The series were first fit to negative or linear exponential functions, and then to a cubic smoothing spline with a $50 \%$ frequency response of 30 years to retain high-frequency variability. The detrended ring-width series were then standardized by transforming them into dimensionless indices by dividing the observed by the expected values given by the functions. Then, autoregressive modeling was performed on each series to obtain residual indexed series. Several descriptive statistics were calculated for the common interval 1980-2005 from the raw tree-ring widths (mean, SE and AC), and the residual chronologies (MSx, rbt, EPS): SE is the standard error of treering widths; $\mathrm{AC}$ is the first-order autocorrelation, a measure of the year-to-year growth similarity; MSx is the mean sensitivity which quantifies the year-toyear variability in width of successive rings; rbt is the mean between-trees correlation which determines the similarity in growth among trees; and the EPS is the expressed population signal which is a parameter indicating the statistical quality of the chronology as compared with an infinitely replicated chronology (for details see Fritts, 1976). The periods in which the growth series showed EPS values higher than 0.85 were considered as well replicated (Wigley et al., 1984).

\subsection{Ground-penetrating radar}

Ground-penetrating radar (GPR) is a time-scaled system that functions by transmitting an electromagnetic wave through the soil. The pulses of electromagnetic energy emitted through the soil have distinct characteristics. Once these pulses contact a boundary layer or an abnormality (i.e., bedrock, soil textural changes, or roots) with varying electromagnetic properties, a portion of this energy is reflected back to the earth's surface. To convert the amount of time for the signal to travel through the soil and back to the surface into a depth scale requires calculating the velocity of pulse propagation (Sucre et al., 2011).

The GPR device used in this study was the Subsurface Interface Radar System-2000 (SIR-2000, Geophysical Survey Systems Inc., North Salem, NH) coupled with a $900-\mathrm{MHz}$ antenna. Ten 50-m transects were randomly established and sampled in the two studied areas (unaffected and affected trees). Soil depth, defined as the total volume of material (soil and unconsolidated rocks) above what would be classified as lithic (Sucre et al., 2011), was the single variable obtained with this technique.

\subsection{Terpenoid analysis}

The analysis of monoterpenes and resin acids were performed on current-year needles, twigs and wood collected during July 2007 from ten affected and ten unaffected trees of the studied Scots pine population. The sampling was carried out following the methodology proposed by Manninen et al. (2002). Needles and twigs were collected from the middle of a lateral branch of the uppermost part of the tree and wood samples (disks about $5 \mathrm{~mm}$ thick) were obtained from the main stem of the fourth annual growth of each tree. The samples were stored in a cool bag and carried out to the laboratory. Once there, the samples were stored in a deep freezer $\left(-80^{\circ} \mathrm{C}\right)$ and lyophilized. Approximately $2 \mathrm{~g}$ in fresh weight of needles, twigs (bark detached) and stem disks (bark detached) were cut into small pieces and extracted at room temperature with $18 \mathrm{ml}$ of a mixture containing $n$-hexane + diethyl ether 1:1 (v/v) for $1 \mathrm{~h}$. The extracts were dried with nitrogen and redissolved in $10 \mathrm{ml}$ of the mixture used for extraction. Terpenoids were analysed by gas chromatography-mass spectrometry (Agilent Technologies 5973) equipped with a HP$5 \mathrm{MS}$ column $(30 \mathrm{~m} \times 0.25 \mathrm{~mm}$ i.d., $0.25 \mu \mathrm{mm}$ film thickness). Helium was used as a carrier gas. For the quantification of monoterpenes, hexadecane was used as an internal standard. For resin acids analysis, samples were derivatized with bis-(trimethylsilyl)-trifluoroacetamide (BSTFA) with addition of $1 \%$ trimethylchlorosilane (Sigma Aldrich). On this occasion heptadecanoic acid was added as an internal standard. The initial column temperature was $60{ }^{\circ} \mathrm{C}$ rising to $270{ }^{\circ} \mathrm{C}$ at 5 ${ }^{\circ} \mathrm{C} / \mathrm{min}$ where it was held for $15 \mathrm{~min}$. The mass spectrometer was operated in the electron impact and the detection was performed in the full scan mode from $\mathrm{m} / \mathrm{z} 60$ to 450 . Individual monoterpenes and resin acids were identified by their retention times and mass spectra, compared with those in databases (Wiley275, NIST02).

\subsection{Statistical analysis}

All values are expressed as mean values \pm standard error. Comparisons between mean values for affected and unaffected trees were assessed with the Student's t test. All statistical analyses were performed with the program SAS version 8.0 (SAS, Cary, NC, USA).

\section{Results}

Mean radial growth differed between affected and unaffected trees since 2000 (Fig. 1). Affected trees showed a higher mean sensitivity, i.e. a higher year-to- 


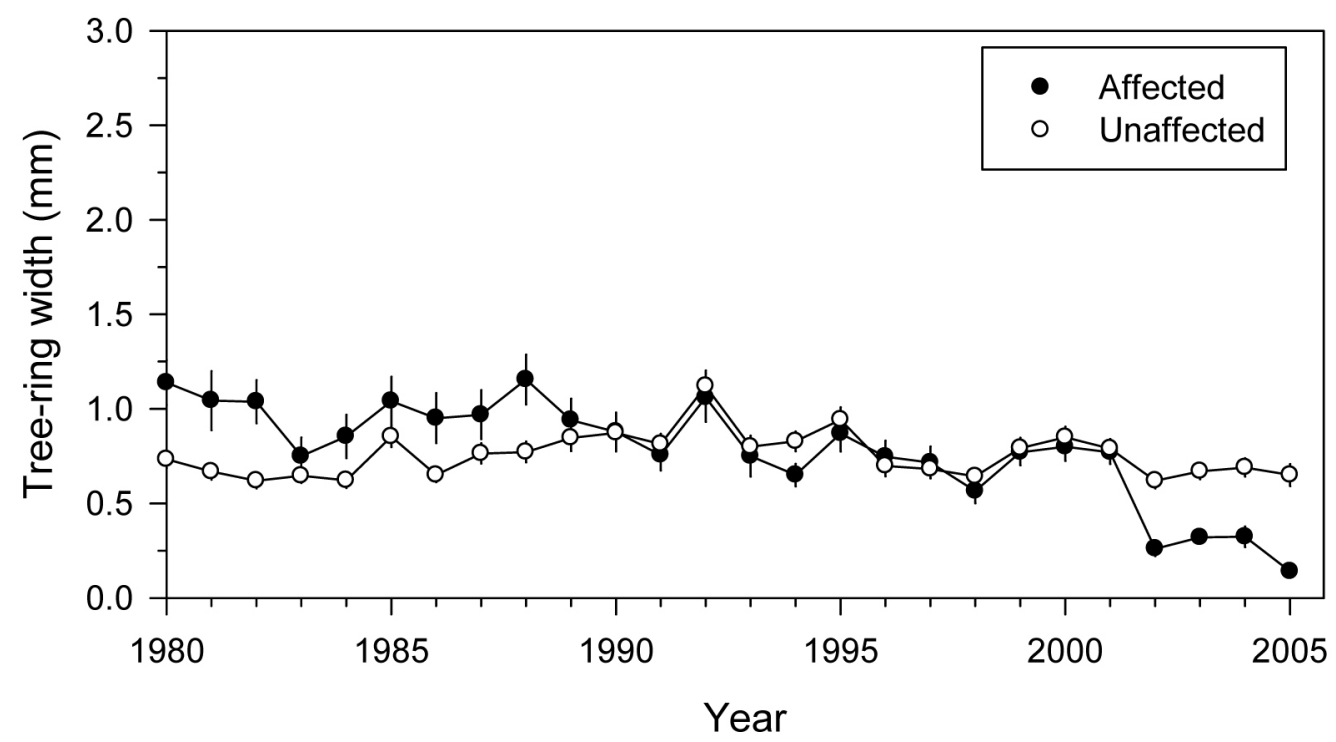

Figure 1: Tree-ring width $(\mathrm{mm})$ of wood samples obtained from unaffected and affected trees of the studied Scots pine population for the 1980-2005 period. Data are mean \pm SE. The error bars are presented in one direction for visual clarity.

Figura 1: Anchura de anillo $(\mathrm{mm})$ de muestras de madera obtenidas de árboles no afectados y afectados de la población estudiada de pino albar para el periodo 1980-2005. Los datos están expresados como media \pm SE. Las barras de error se muestran en una sola dirección por motivos de claridad visual.

year variability in growth, and a higher first-order autocorrelation, i.e. a higher year-to-year persistence in growth, than unaffected trees (Table 1). The soil thickness in the sites where unaffected trees occur was ca. $25 \mathrm{~cm}$ (Fig. 2A), whereas it only reached ca. $5 \mathrm{~cm}$ for unaffected trees (Fig. 2B).

Table 2 shows the concentrations $\left(\mathrm{mg} \mathrm{g}^{-1}\right)$ of monoterpenes and resin acids in needles, twigs and wood of unaffected and affected trees of the studied Scots pine population. As expected, $\alpha$-pinene was the most abundant monoterpene in this species, for all the tissues analysed. The concentrations of individual and total monoterpenes did not show statistically significant differences at $\mathrm{P}<0.05$ between unaffected and affected trees for needles, twigs and wood (Table 2). By contrast, the concentration of total resin acids in the affected trees were significantly higher $(\mathrm{P}<0.05)$ in needles and twigs (Table 2). This increase was mainly due to the abietane type resin acids and, specifically, to the abietic and dehydroabietic acids (Table 2). The pimarane type resin acids also increased in the affected trees, although this change was only statistically significant $(\mathrm{P}<0.05)$ in twigs, mainly due to the pimaric and isopimaric acids (Table 2).

\section{Discussion}

In this study we have analysed the changes in the terpenoid profile between affected and unaffected trees of the studied Scots pine population (Table 2). At first glance, it should be highlighted the differential performance found between resin acids and monoterpenes, the volatile fraction of the terpenoid profile. The total amount of resin acids in the affected trees were significantly increased $(\mathrm{P}<0.05)$ for all the tissues analysed, mainly due to the abietane type resin acids (Table 2). Specifically, the concentration of abietic acid in affected trees is nearly twice higher than in unaffected trees, irrespective of the plant material (needles, twigs, wood) considered. Turtola et al. (2003) also reported a shift in the amount of the abietane type resin acids in drought stressed Scots pine seedlings, highlighting the protective role of these compounds against fungi. We also found a shift in the pimarane type resin acids in the twigs of affected trees, as previously described by Turtola et al. (2003).

Regarding monoterpenes, we did not find statistically significant differences in the amount of these compounds between affected and unaffected trees, although a slight shift in needles and wood were observed, mainly attributable to changes in the $\alpha$-pinene (Table 2). Several studies have associated changes in the amount of monoterpenes with water stress. Thus, Kainulainen et al. (1992) reported a significantly higher amount of total monoterpenes in water stressed needles of Picea abies, with $\alpha$-pinene and camphene showing the strongest positive response to drought. More recently, Turtola et al. (2003) reported that drought increased the concentration of $\alpha$-pinene and camphene in needles of Pinus sylvestris. However, Yani et al. (1993), when studied the effect of long-term water stress on terpene content of the foliage of Cupressus sempervirens, found that the concentration of $\alpha$-pinene, $\beta$-pinene, sabinene, terpinolene, myrcene and limonene did not show noticeable changes until the leaf water content ( $\mathrm{mg} \mathrm{g}^{-1}$ fresh weight) were ca. $80 \%$ of the initial value. It should be noted that the concentration of these compounds showed a strong 
CHANGE IN THE TERPENOID PROFILE AND SECONDARY GROWTH IN DECLINING STANDS... 5
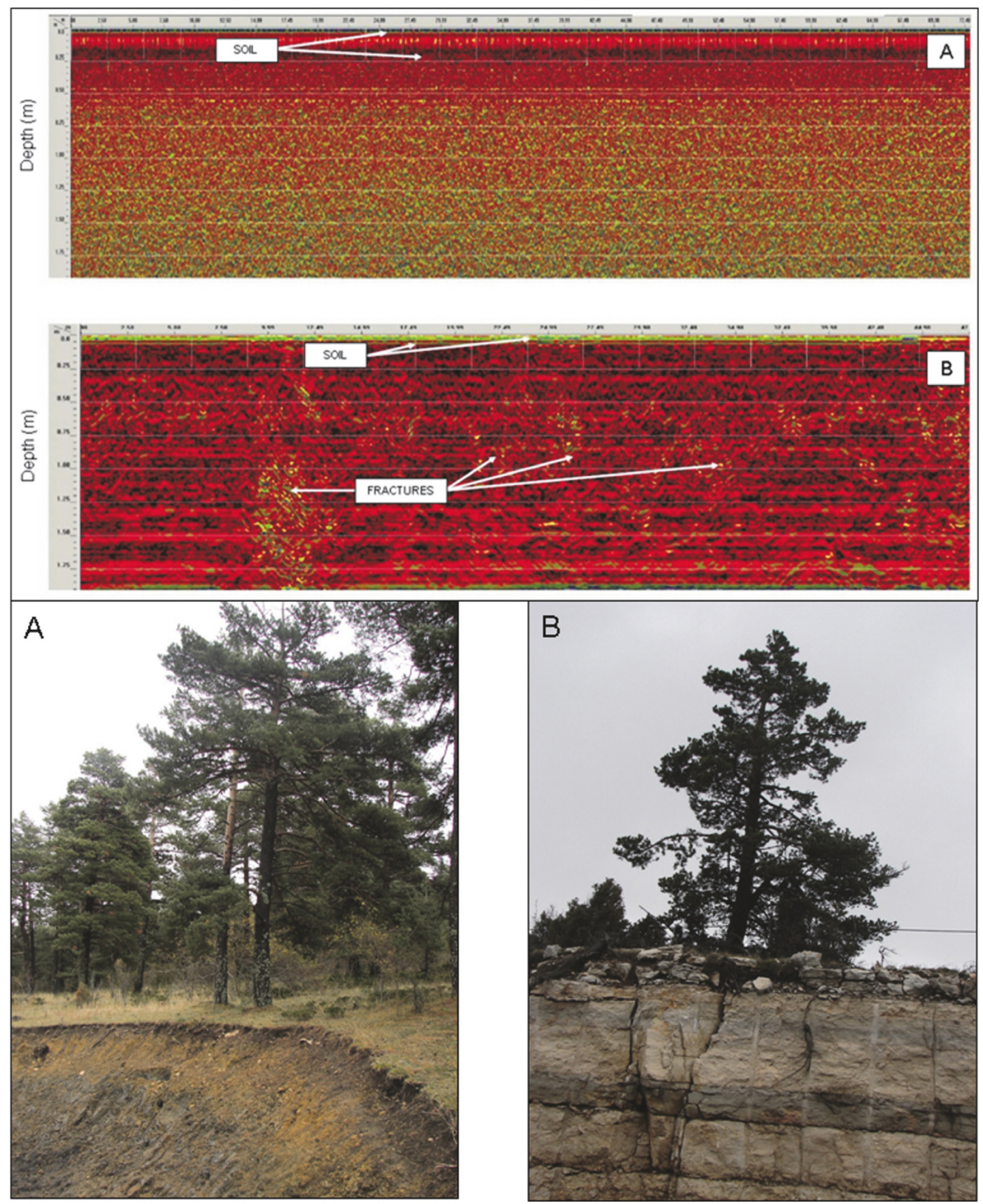

Figure 2: Ground-penetrating radar records for soils where unaffected (A) and affected trees $(\mathbf{B})$ occurs.

Figura 2: Registros del radar de penetración en el terreno para suelos sobre los que crecen los árboles no afectados (A) y afectados

(B).

Table 1: Dendrochronological statistics of unaffected and affected trees of the studied Scots pine population. Different letters indicate significant differences at $\mathrm{P}<0.05$.

Tabla 1: Concentraciones ( $\mathrm{mg}$ g-1) de monoterpenos y ácidos resínicos en acículas, ramillos y madera en árboles no afectados y afectados de la población estudiada de pino albar. Los datos están expresados como media $\pm S E$. Letras diferentes indican diferencias significativas a $P<0.05$.

\begin{tabular}{|l|c|c|c|c|c|c|c|}
\cline { 2 - 8 } \multicolumn{1}{c|}{} & & \multicolumn{2}{c|}{ Tree-ring width $(\mathbf{m m})$} & \multicolumn{2}{c|}{ Mean sensitivity } & \multicolumn{2}{c|}{ First-order autocorrelation } \\
\cline { 2 - 8 } & $\begin{array}{c}\text { No trees } \\
\text { (radii) }\end{array}$ & $\mathbf{1 9 8 0 - 2 0 0 5}$ & $\mathbf{2 0 0 0 - 2 0 0 5}$ & $\mathbf{1 9 8 0 - 2 0 0 5}$ & $\mathbf{2 0 0 0 - 2 0 0 5}$ & $\mathbf{1 9 8 0 - 2 0 0 5}$ & $\mathbf{2 0 0 0 - 2 0 0 5}$ \\
\hline Unaffected & $10(20)$ & $0.76 \pm 0.12$ & $0.71 \pm 0.09 \mathrm{~b}$ & 0.13 & 0.11 & 0.32 & 0.25 \\
\hline Affected & $10(20)$ & $0.78 \pm 0.27$ & $0.44 \pm 0.28 \mathrm{a}$ & 0.22 & 0.42 & 0.62 & 0.33 \\
\hline
\end{tabular}


Table 2: Concentrations $\left(\mathrm{mg} \mathrm{g}^{-1}\right)$ of individual monoterpenes and resin acids in needles, twigs and wood of unaffected and affected trees of the studied Scots pine population. Data are mean \pm SE. Different letters indicate significant differences at $\mathrm{P}<0.05$.

Tabla 2: Concentraciones ( $\mathrm{mg}$ g-1) de monoterpenos y ácidos resínicos en acículas, ramillos y madera en árboles no afectados y afectados de la población estudiada de pino albar. Los datos están expresados como media $\pm S E$. Letras diferentes indican diferencias significativas a $P<0.05$.

\begin{tabular}{|c|c|c|c|c|c|c|}
\hline & \multicolumn{2}{|c|}{ Needle } & \multicolumn{2}{|c|}{ Twig } & \multicolumn{2}{|c|}{ Wood } \\
\hline & Unaffected & Affected & Unaffected & Affected & Unaffected & Affected \\
\hline \multicolumn{7}{|l|}{ Monoterpenes } \\
\hline$\alpha$-Pinene & $2.18 \pm 0.72$ & $2.52 \pm 0.38$ & $4.06 \pm 1.36$ & $2.95 \pm 0.62$ & $1.71 \pm 0.65$ & $2.12 \pm 0.53$ \\
\hline Camphene & $0.51 \pm 0.18$ & $0.50 \pm 0.05$ & $0.06 \pm 0.02$ & $0.03 \pm 0.01$ & $0.02 \pm 0.01$ & $0.03 \pm 0.01$ \\
\hline Sabinene & $0.03 \pm 0.01$ & $0.02 \pm 0.00$ & $0.01 \pm 0.00$ & $0.01 \pm 0.00$ & $0.01 \pm 0.00$ & $0.01 \pm 0.00$ \\
\hline$\beta$-Pinene & $0.29 \pm 0.09$ & $0.64 \pm 0.32$ & $0.81 \pm 0.69$ & $1.02 \pm 0.55$ & $0.40 \pm 0.35$ & $0.80 \pm 0.60$ \\
\hline Myrcene & $0.09 \pm 0.04$ & $0.08 \pm 0.01$ & $0.07 \pm 0.03$ & $0.04 \pm 0.01$ & $0.01 \pm 0.00$ & $0.01 \pm 0.00$ \\
\hline Limonene & $0.02 \pm 0.01$ & $0.03 \pm 0.00$ & $0.07 \pm 0.04$ & $0.01 \pm 0.01$ & $0.01 \pm 0.00$ & $0.01 \pm 0.00$ \\
\hline Ocimene & $0.07 \pm 0.03$ & $0.09 \pm 0.02$ & $0.00 \pm 0.00$ & $0.00 \pm 0.00$ & $0.00 \pm 0.00$ & $0.00 \pm 0.00$ \\
\hline Terpinolene & $0.01 \pm 0.00$ & $0.01 \pm 0.00$ & $0.01 \pm 0.00$ & $0.01 \pm 0.00$ & $0.01 \pm 0.00$ & $0.01 \pm 0.00$ \\
\hline \multicolumn{7}{|l|}{ Resins acids } \\
\hline \multicolumn{7}{|c|}{ Pimarane type resin acids } \\
\hline Pimaric acid & $0.06 \pm 0.01$ & $0.07 \pm 0.01$ & $0.59 \pm 0.04 \mathrm{a}$ & $0.81 \pm 0.08 \mathrm{~b}$ & $0.24 \pm 0.06$ & $0.30 \pm 0.07$ \\
\hline $\begin{array}{l}\text { Sandaracopimaric } \\
\text { acid }\end{array}$ & $0.06 \pm 0.01$ & $0.07 \pm 0.01$ & $0.17 \pm 0.04$ & $0.24 \pm 0.08$ & $0.10 \pm 0.02$ & $0.11 \pm 0.02$ \\
\hline Isopimaric acid & $0.15 \pm 0.02$ & $0.19 \pm 0.02$ & $1.60 \pm 0.35 \mathrm{a}$ & $3.31 \pm 0.71 \mathrm{~b}$ & $0.52 \pm 0.13$ & $0.78 \pm 0.19$ \\
\hline \multicolumn{7}{|c|}{ Abietane type resin acids } \\
\hline Abietic acid & $0.72 \pm 0.15 \mathrm{a}$ & $1.12 \pm 0.15 \mathrm{~b}$ & $7.58 \pm 0.68 \mathrm{a}$ & $11.27 \pm 1.42 \mathrm{~b}$ & $2.51 \pm 0.66 \mathrm{a}$ & $4.66 \pm 0.88 b$ \\
\hline Palustric acid & $0.13 \pm 0.03$ & $0.19 \pm 0.02$ & $3.35 \pm 0.49$ & $4.78 \pm 0.61$ & $1.17 \pm 0.31$ & $1.78 \pm 0.43$ \\
\hline $\begin{array}{l}\text { Dehydroabietic } \\
\text { acid }\end{array}$ & $1.65 \pm 0.32 \mathrm{a}$ & $2.46 \pm 0.23 \mathrm{~b}$ & $9.00 \pm 2.52$ & $12.74 \pm 2.74$ & $3.54 \pm 0.53$ & $4.94 \pm 1.06$ \\
\hline Neoabietic acid & $0.16 \pm 0.04$ & $0.15 \pm 0.01$ & $0.74 \pm 0.06 \mathrm{a}$ & $1.11 \pm 0.09 \mathrm{~b}$ & $0.27 \pm 0.06$ & $0.32 \pm 0.07$ \\
\hline
\end{tabular}

and regular decrease later, to a final value of less than $5 \%$ of the initial values, once the water content of the plant organs stabilized in a value close to $50 \%$ of the initial one.

Although the terpenoid profile seems to be influenced by genetic, as has been found in different pine species (Squilace et al., 1980; Latta et al., 2003; Arrabal et al., 2005; Karanikas et al., 2010), including $P$. sylvestris (Baradat \& Yazdani, 1988; Manninen et al., 2002; Semiz et al., 2007), here we reported changes which hardly can be attributed to genetic causes, as long as both kinds of trees grow in a close area. As suggested above, local factors (mainly soil depth and its effect on water economy) may influence the physiology of both types of pine specimens. We hypothesize that a tradeoff between growth and defence might explain the influence of stress factors (specially drought) in the oleoresin production as a consequence of changes in the allocation patterns (Gaylord et al., 2007), following the postulates of the Growth Differentiation Balance Hypothesis (GDBH) (Lerdau et al., 1994; Glynn et al., 2007). In this way, the tree-ring width comparison between both kind of trees reflected a marked reduction since 2002, which has been shown that is clearly influenced by the precipitation amounts in June and July during the year of tree-ring formation (Camarero \& Sancho, 2006). The proximity of both kind of trees (ca. $500 \mathrm{~m}$ ) implies that a local factor should be responsible for these differences. In this way, the sensitivity of the affected trees was statistically significant higher in the affected trees (Table
1), which has been related to soil scarcity (Candel-Pérez et al., 2012). The results obtained by the use of GPR clearly confirm that the two kinds of trees grow in markedly different soils in terms of depth (Fig. 2), which is expected to drastically affect the soil water reserves. The xylem water potential values registered for both kinds of trees during two consecutive vegetative periods (2005 and 2006) by Peguero Pina et al. (2011) seem to confirm this idea. Thus, the minimum seasonal water potential during summer in trees growing in the shallowest soils (ca.-2 MPa) were lower than that registered in the trees growing in the deepest soil (ca. -1.5 MPa).

Drought, as a stress factor limiting plant growth, should induce the investment of the carbohydrates fixed in photosynthesis in the synthesis of secondary metabolites, yielding a higher concentration of the different compounds constituting the oleoresin (Turtola et al., 2003). However, as stated above, a decrease in the quantity of oleoresin can be induced once the water stress reaches a certain physiological threshold (Hodges \& Lorio, 1975).

\section{Conclusions}

The use of the terpenoid profile can be considered a promising tool for the detection of water stress in pines and other conifers, due to the accumulation of evidences that confirm a shift in some compounds (mainly resin acids) in water stressed specimens of these plants (Tur- 
tola et al., 2003). This fact implies that the change in the terpenoid profile can be used for detecting situations inducing moderate but relatively prolonged stress conditions, as long as it has been suggested that the production of oleoresins is impaired at higher level of water stress.

\section{Acknowledgements}

This study was partially supported by a specific collaboration agreement between CITA-Aragón and Departamento de Medio Ambiente-Gobierno de Aragón and by the project AGL2010-21153-C02-02 (Ministerio de Economía y Competitividad). Financial support from Gobierno de Aragón (A54 research group) is also acknowledged. The work of José Javier Peguero-Pina is supported by a "Juan de la Cierva" post-doctoral contract (Ministerio de Economía y Competitividad).

\section{References}

Alía, R., Moro-Serrano, J. \& Notivol, E. 2001. Genetic variability of Scots pine (Pinus sylvestris) provenances in Spain: growth traits and survival. Silva Fennica, 35: 27-38.

Andersson, B. \& Fedorkov, A. 2004. Longitudinal differences in Scots pine frost hardiness. Silvae Genetica, 53: 76-80.

Arrabal, C., Cortijo, M., de Simon, B.F., García-Vallejo, M.C. \& Cadahia, E. 2005. Differentiation among five Spanish Pinus pinaster provenances based on its oleoresin terpenic composition. Biochemical Systematics and Ecology, 33: 1007-1016. doi: http://dx.doi.org/10.1016/j.bse.2005.03.003.

Baradat, P.H. \& Yazdani, R. 1988. Genetic expression for monoterpenes in clones of Pinus sylvestris grown on different sites. Scandinavian Journal of Forest Research, 3: 25-36. doi: http://dx.doi.org/10.1080/02827588809382492

Blodgett, J.T. \& Stanov, G.R. 1996. Monoterpene and phenolic compounds concentrations in water-stressed red pine inoculated with Sphaeropsis sapinea. Phytopathology, 88: 245-251. http://dx.doi.org/10.1094/PHYTO.1998.88.3.245

Camarero, J.J. \& Sancho, S. 2006. Dendroecología, decaimiento del bosque y relaciones no lineares entre clima y crecimiento radial. En: Cuadrat Prats, J.M., Saz Sánchez, M.A., Vicente Serrano, S.M., Lanjeri, S., de Luis Arrillaga, M. \& González-Hidalgo, J.C., (eds.) Publicaciones de la Asociación Española de Climatología, Serie A, $n^{\circ} 5.837$ pp., Sdad Coop de Artes Gráficas, Librería General, Zaragoza.

Candel-Pérez, D., Linares, J.C., Vinegla, B. \& Lucas-Borja, M.E. 2012. Assessing climate-growth relationships under contrasting stands of co-occurring Iberian pines along an altitudinal gradient. Forest Ecology and Management, 274: 48-57. doi: http:// dx.doi.org/10.1016/j.foreco.2012.02.010.

Catalán, G., Gil, P., Galera, R., Martín, S., Agúndez, D. \& Alía, R. 1991. Las regiones de procedencia de Pinus sylvestris $L$. $y$ Pinus nigra Arn. subsp. salzmanii (Dunal) Franco en España. ICONA, Madrid.

Cook, E.R. 1985. A time series analysis approach to tree-ring standardization. $\mathrm{PhD}$ thesis, Department of Geosciences, 171 pp., University of Arizona, Tucson.

Corcuera, L., Gil-Pelegrín, E. \& Notivol, E. 2012. Aridity promotes differences in proline and phytohormone levels in Pinus pinaster populations from contrasting environments. Trees, Structure and Function, 26: 799-808. doi: http://dx.doi.org/10.1007/ s00468-011-0651-x

Croisé, L. \& Lieutier, F. 1993. Effects of drought on the induced defence reaction of Scots pine to bark beetle-associated fungi. Annals of Forest Science, 50: 91-97. doi: http://dx.doi.org/ 10.1051/forest: 19930107
Fritts, H.C. 1976. Tree rings and climate. Academic Press, 576 pp., New York.

Galiano, L., Martínez-Vilalta, J. \& Lloret, F. 2010. Drought-induced multifactor decline of Scots Pine in the Pyrenees and potential vegetation change by the expansion of co-occurring oak species. Ecosystems, 13: 978-991. doi: http://dx.doi.org/10.1007/ s10021-010-9368-8.

Gaylord, M.L., Kolb, T.E., Wallin, K.F. \& Wagner, M.R. 2007. Seasonal dynamics of tree growth, physiology, and resin defenses in a northern Arizona ponderosa pine forest. Canadian Journal of Forest Research, 37: 1173-1183. doi: http://dx.doi.org/ 10.1139/X06-309.

Glynn, C., Herms, D.A., Orians, C.M., Hansen, R.C. \& Larsson, S. 2007. Testing the growth-differentiation balance hypothesis: dynamic responses of willows to nutrient availability. New Phytologist, 176: 623-634. doi: http://dx.doi.org/10.1111/ j.1469-8137.2007.02203.x.

Hodges, J.D. \& Lorio, P.L. 1975. Moisture stress and composition of xylem oleoresin in loblolly pine. Forest Science, 21: 283-290.

Holmes, R.L. 1983. Computer-assisted quality control in tree-ring dating and measurement. Tree-Ring Bulletin, 43: 68-78.

Kainulainen, P., Holopainen, J., Palomäki, V. \& Holopainen, T. 1996. Effects of nitrogen fertilization on secondary chemistry and ectomycorrhizal state of Scots pine seedlings and on growth of grey pine aphid. Journal of Chemical Ecology, 22: 617-636. doi: http://dx.doi.org/10.1007/BF02033574.

Kainulainen, P.J., Oksanen, J., Palomäki, V., Holopainen, J.K. \& Holopainen, T. 1992. Effect of drought and waterlogging stress on needle monoterpenes of Picea abies. Canadian Journal of Botany, 70: 1613-1616. doi: http://dx.doi.org/10.1139/b92-203.

Karanikas, C., Walker, V., Scaltsoyiannes, A., Comte, G. \& Bertrand, C. 2010. High vs. low yielding oleoresin Pinus halepensis Mill. trees GC terpenoids profiling as diagnostic tool. Annals of Forest Science, 67: 412. doi: http://dx.doi.org/10.1051/forest/2009132.

Latta, R.G., Linhart, Y.B., Snyder, M.A. \& Lundquist, L. 2003. Patterns of variation and correlation in the monoterpene composition of xylem oleoresin within populations of ponderosa pine. Biochemical Systematics and Ecology, 31: 451-465. doi: http://dx.doi.org/10.1016/S0305-1978(02)00176-X.

Lerdau, M., Litvak, M. \& Monson, R. 1994. Plant chemical defense: monoterpenes and the growth-differentiation balance hypothesis. Trends in Ecology and Evolution, 9: 58-61. doi: http:// dx.doi.org/10.1016/0169-5347(94)90269-0

Llusià, J. \& Peñuelas, J. 1998. Changes in terpene content and emission in potted Mediterranean woody plants under severe drought. Canadian Journal of Botany, 76: 1366-1372. doi: $\mathrm{http} / / / \mathrm{dx}$. doi.org/10.1139/b98-141

Lombardero, M.J., Ayres, M.P., Lorio, P.L. \& Ruel, J.J. 2000. Environmental effects on constitutive and inducible resin defences of Pinus taeda. Ecology Letters, 3: 329-339. doi: http://dx.doi.org/ 10.1046/j.1461-0248.2000.00163.x.

Manninen, A.M., Tarhanen, S., Vuorinen, M. \& Kainulainen, P. 2002. Comparing the variation of needle and wood terpenoids in Scots pine provenances. Journal of Chemical Ecology, 28: 211-228. doi: http://dx.doi.org/10.1023/A:1013579222600.

Martínez-Vilalta, J. \& Piñol, J. 2002. Drought-induced mortality and hydraulic architecture in pine populations of the NE Iberian Peninsula. Forest Ecology and Management, 161: 247-256. doi: http://dx.doi.org/10.1016/S0378-1127(01)00495-9.

Matías, L. \& Jump, A.S. 2012. Interactions between growth, demography and biotic interactions in determining species range limits in a warming world: The case of Pinus sylvestris. Forest Ecology and Management, 282: 10-22. doi: http://dx.doi.org/ $10.1016 / \mathrm{j}$.foreco.2012.06.053

Peguero-Pina, J.J., Alquézar-Alquézar, J.M., Mayr, S., Cochard, H. \& Gil-Pelegrín, E. 2011. Embolism induced by winter drought may be critical for the survival of Pinus sylvestris L. near its southern distribution limit. Annals of Forest Science, 68: 565-574. doi: http://dx.doi.org/10.1016/j.flora.2006.06.004.

Poyatos, R., Llorens, P., Piñol, J. \& Rubio, C. 2008. Response of Scots pine (Pinus sylvestris L.) and pubescent oak (Quercus pubescens Willd.) to soil and atmospheric water deficits under 
Mediterranean mountain climate. Annals of Forest Science, 65: 306. doi: http://dx.doi.org/10.1051/forest:2008003.

Semiz, G., Heijari, J., Isik, K. \& Holopainen, J.K. 2007. Variation in needle terpenoids among Pinus sylvestris L. (Pinaceae) provenances from Turkey. Biochemical Systematics and Ecology, 35: 652-661. doi: http://dx.doi.org/10.1016/j.bse.2007.05.013.

Squilace, A.R., Schreuder, H.T. \& Bhattacharyya, H.T. 1980 Identification of seed origin of slash pine plantations. Silvae Genetica, 29: 152-154.

Sucre, E.B., Tuttle, J.W. \& Fox, T.R. 2011. The use of ground-penetrating radar to accurately estimate soil depth in rocky forest soils. Forest Science, 57: 59-66.

Turtola, S., Manninen, A.N., Rikala, R. \& Kainulainen, P. 2003. Drought stress alters the concentration of wood terpenoids in Scots pine and Norway spruce seedlings. Journal of Chemical
Ecology, 29: 1981-1994. doi: http://dx.doi.org/10.1023/ A:1025674116183.

Wigley, T.M.L., Briffa, K.R. \& Jones, P.D. 1984. On the average of correlated time series, with applications in dendroclimatology and hydrometeorology. Journal of Climate and Applied Meteorology, 23: 201-213. doi: http://dx.doi.org/10.1175/ 1520-0450(1984)023<0201:OTAVOC $>2.0 . C O ; 2$

Xiao, X., Xu, X. \& Yang, F. 2008. Adaptive responses to progressive drought stress in two Populus cathavana populations. Silva Fennica, 42: 705-719. doi: http://dx.doi.org/10.14214/sf.224

Yani, A., Pauli, G., Faye, M., Salin, F. \& Gleizes, M. 1993. The effect of a long-term water stress on the metabolism and emission of terpenes of the foliage of Cupressus sempervirens. Plant, Cell and Environment, 16: 975-981. doi: http://dx.doi.org/10.1111/ j.1365-3040.1993.tb00521.x 